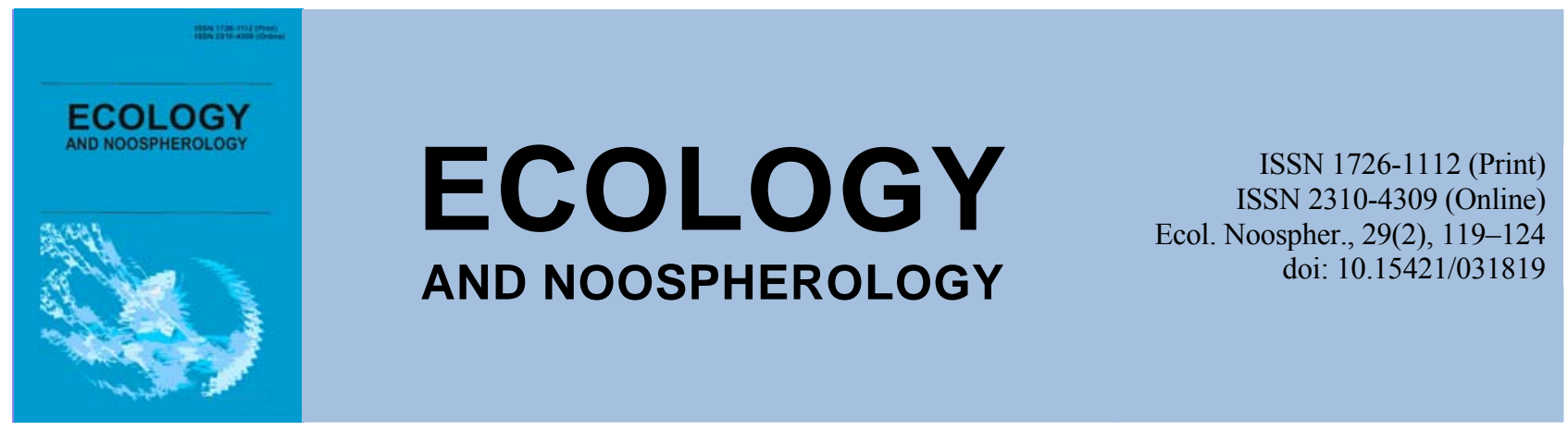

\title{
Bioecological analysis of Picea pungens needles in the deterioral conditions of the DTEK Prydniprovsk thermal power plant
}

\author{
T. I. Yusypiva
}

Oles Honchar Dnipro National University, Dnipro, Ukraine

Article info

Received 10.10.2018

Received in revised form 19.10.2018

Accepted 25.10.2018

Oles Honchar Dnipro

National University

Gagarin Ave., 72, Dnipro, 49010, Ukraine.

Tel.: +38-096-836-03-37

E-mail: JusypivaTatjana@i.ua
Yusypiva, T. I. (2018). Bioecological analysis of Picea pungens needles in the deterioral conditions of the DTEK Prydniprovsk thermal power plant. Ecology and Noospherology, 29(2), 119-124. doi:10.15421/031819

Crucial for the research on adaptiogenesis of introduced coniferous species is the study the anatomical structure of their vegetative organs, especially the needles, which provides the productivity of individual trees and plantings in general. In conditions of anthropogenic pressure of the environment there are changes in the thickness and structure of the histological elements of vegetative organs of coniferous species, in the first place, protective tissues. Therefore, the study of the anatomical structure of the needles is relevant in the context of studying the ways and mechanisms of adaptation of gymnosperms to industrial emissions and the finding sensitive phytoindicators of environmental pollution and the condition of coniferous plants in man-made zones. However, today the chronic effect of phytotoxicants on the anatomical structure of needles is insufficiently studied. Ecological and anatomical studies of $P$. pungens in the conditions of the steppe zone of Ukraine for the effects of technogenesis are practically absent. Prydniprovsk TPP is the largest source of pollution in the city of Dnipro (Ukraine): its emissions make up $68,9 \%$ of the volume of toxic compounds of all enterprises and transport facilities. The main pollutants of emissions from Prydniprovsk TPP are $\mathrm{SO}_{2}, \mathrm{NO}_{2}$, solids, $\mathrm{CO}$. In order to reduce the negative impact of the TPP emissions, green plantations mainly from softwood are created around it, which purify the atmosphere and improve the environment throughout the year. In view of this, the purpose of the work is to analyse the state of morphological and anatomical indices of the Picea pungens Engelm f. glauca Beissn. needles under the influence of emissions from Prydniprovsk TPP. The research is conducted according to generally accepted methods (Zlobin et al., 2009; Albrechtova, 2003; Permjakov, 1988). It has been found that the length and weight of needles in experimental specimens of $P$. pungens decrease with respect to the values of these indices in plants of relatively pure zone; therefore, they are sensitive growth parameters to the action of environmental pollution. Nevertheless, the intensity of the growth of $P$. pungens needles does not change; therefore, it is not an informative feature for assessing the living conditions of the prickly fir in the industrial zone. The analysis of the micromorphological features of $P$. pungens needles showed resistance to anthropogenic pressure of its characteristics, such as width and thickness, although the area of needles decreases, which is associated with a significant decrease in the technogenic conditions of the environment of its length. In plants of P. pungens, growing on the territory adjacent to Prydniprovsk TPP, the size of the constituents of needles of $P$. pungens (epidermis and hypoderms), as well as the number, diameter and type of placement of resin passages in the mesophyll of the needles do not differ significantly from such indices in plants of relatively pure zone indicating the stability of these features and the resistance of the needles of the investigated species to the emissions of TPP. The thickness of the assimilation parenchyma from the adaxial side of the needle of $P$. pungens in the conditions of technogenesis increases. Among the histological elements of the needles P.pungens the greatest influence of man-made emissions is experienced by the components of the central conductive cylinder: the layer of endoderm thickens by $15,9 \%$, as compared with the control value, which we consider as an adaptive reaction of plants to man-made stress; the diameter of the central conductive cylinder and the thickness of xylem increases. Probably this is due to the need for better water supply of plants. Thus, in the conditions of technogenesis, stability of the histological characteristics and plasticity of the morphometric characteristics of the needles P. pungens were revealed. The formation of adaptive mechanisms of compensatory type in the needles of $P$. pungens under the influence of phytotoxicants was found: there is an increase of the size of the endoderm, 
mesophyll, xylem and the central conductive cylinder of the needles. It is shown that the ratio of particles of histological structures of needles (in \%) to the action of pollutants of TPP remains practically unchanged. The informative test parameters for monitoring studies of the condition of coniferous plants in man-made zones (mass, length and area of needles) are suggested. Estimation of $P$. pungens resistance to the components of the thermal power plant's emissions as a mediumresistant species. It is recommended to use $P$. pungens in landscaping of contaminated areas.

Keywords: Picea pungens Engelm.; morphometric indices; micromorphological characteristics; anatomical parameters; needles; technogenic contamination

\title{
Біоекологічний аналіз стану хвої Picea pungens в умовах викидів ДТЕК «Придніпровська ТЕС»
}

\author{
Т. І. Юсипіва
}

Дніпровський національний університет імені Олеся Гончара, Дніпро, Україна

Проаналізовано вплив забруднення середовища викидами ДТЕК «Придніпровська ТЕС» (м. Дніпро) на морфоанатомічні показники листка Picea pungens Engelm. f. glauca Beissn. Виявлено стабільність гістологічних і пластичність морфометричних ознак хвої P.pungens в умовах техногенезу. Встановлено формування адаптивних механізмів компенсаторного типу в хвоїнках P.pungens під впливом фітотоксикантів: збільшення розмірів ендодерми, мезофілу, ксилеми та центрального провідного циліндра хвоїнки. Запропоновано інформативні тест-параметри для моніторингових досліджень стану хвойних рослин у техногенних зонах (маса, довжина, площа хвоїнки). Рекомендовано використовувати $P$. pungens в озелененні територій, забруднених $\mathrm{SO}_{2}, \mathrm{NO}_{2}$, твердими домішками та $\mathrm{CO}$.

Ключові слова: Picea pungens Engelm.; морфометричні показники; мікроморфологічні характеристики; анатомічні параметри; хвоя; техногенне забруднення

\section{Вступ}

Дніпро - потужний промисловий центр України (Тhe City of Dnipropetrovsk, 2015), в якому працюють понад 200 підприємств. Щорічно вони забруднюють атмосферне повітря, водні басейни та грунт міліонами тон токсичних речовин, що порушує нормальне функціонування як природних, так i штучних лісових екосистем. ДТЕК «Придніпровська ТЕС» - найбільше джерело забруднення: ii емісії становлять $68,9 \%$ від обсягу забруднювальних сполук усіх підприємств і транспортних об'єктів м. Дніпра (Ecological passport of the Dnipro Sity, 2016). Для зменшення негативного впливу викидів ТЕС навколо неї створені зелені насадження переважно із хвойних порід, які очищують атмосферне повітря й оздоровлюють навколишнє середовище протягом усього року.

Техногенне забруднення довкілля змінює функціонування рослинних організмів на всіх рівнях їх організації, у тому числі клітинному, тканинному, органному (Bessonova, 2006; Griztay \& Shupranova, 2015; Iusypiva \& Miasoid, 2017). За дії стресових умов зростання серед реакцій-відповідей рослин на вплив токсичних речовин наявні зміни в розмірах річних приростів пагонів та асиміляційних органів, процесах формування листового апарату, у закладанні й розвитку репродуктивних структур, у процесах проростання насіння та формування сходів, самосіву та підросту головних i супутніх лісоутворювальних деревних порід (Bessonova \& Usypiva, 2001; Stasova et al., 2009; Grytsay \& Miasoid, 2016).

Важливу роль у вивченні адаптогенезу хвойних інтродуцентів мають дослідження анатомічної структури ïx вегетативних органів, особливо хвої, яка забезпечує продуктивність окремих дерев і насадження в цілому (Bessonova \& Iusypiva, 2018). В умовах антропогенного тиску довкілля спостерігаються зміни у товщині й будові гістологічних елементів вегетативних органів хвойних порід (Antonova \& Stasova, 2002; Dmuchowski et al., 1998), i в першу чергу покривних і захисних тканин (Fedorkov, 2011; Legoshchina et al., 2013). Тому дослідження анатомічної структури хвої актуальні у контексті вивчення шляхів i механізмів адаптації голонасінних до промислових емісій і виявлення чутливих показників для фітоіндикації забруднення довкілля та стану хвойних рослин у техногенних зонах.

Однак на сьогодні хронічний вплив емісій ТЕС на гістологічну будову хвої вивчений недостатньо. Екологоанатомічні дослідження $P$. pungens в умовах степової зони України за дії техногенезу відсутні. Зважаючи на це, мета роботи - проаналізувати стан морфологічних i анатомічних показників хвої Picea pungens Engelm за дії викидів ДТЕК «Придніпровська ТЕС».

\section{Матеріали та методи досліджень}

Матеріал збирали у травні 2018 р. на двох пробних ділянках. Техногенна зона - територія, яка прилягає до ДТЕК «Придніпровська ТЕС». Частка оксиду сульфуру (IV) в іï викидах становить 97,5 \% від вмісту цієї сполуки в емісіях усіх підприємств міста, оксиду нітрогену (IV) $-84,7 \%$, твердих домішок - 64,8 \%, оксиду карбону (II) - 8,6\% (Ecological passport.., 2015). Контрольна (умовно чиста) зона - Ботанічний сад ДНУ, де концентрації забруднювачів не перевищують ГДК (Pasichnyy \& Serdyuk, 2002; Ecological passport.., 2016).

Об'єкт дослідження - ялина колюча Picea pungens Engelm.f. glauca Beissn. (рід Ялина (Picea А. Dietr.). Проби хвоїнок відбирали 3 минулорічних пагонів подовження скелетних гілок $з$ південно-східного боку 5 модельних дерев на висоті 1,7 м від рівня грунту. Виміри морфометричних показників хвоїнок та їх маси здійснювали у 100-кратній повторності за загальноприйнятими методиками (Zlobin et al., 2009). Коефіцієнт інтенсивності росту хвої розраховували за формулою (Suhareva, 2009): $K=M / L$, де $K-$ коефіцієнт інтенсивності росту хвої, мг/мм; $M$ - маса хвоїнки, мг; $L-$ довжина хвоїнки, мм. Ширину й товщину (висоту) хвоїнки визначали на зрізах у центральній ऑii частині під мікроскопом Levenhuk 2L/3L/D2L за збільшення $7 \times 10$. Зрізи робили 3 використанням ручного мікротома (Permjakov, 1988). Вимірювання розмірів гістологічних елементів хвої здійснювали у 30-кратній повторності за допомогою окуляр-мікрометра за збільшення в 70 разів 
після забарвлювання зрізів флороглюцином (Albrechtova, 2003). Площу хвоїнки розраховували за формулою (Sungurova, Khudyakov, 2015): $S=5,14 L \cdot(a+b / 2) / 2$, де $S$ площа хвоїнки, мм ${ }^{2} ; L-$ довжина хвоїнки, мм; $a$ - товщина хвоїнки, мм; $b$ - ширина хвоїнки, мм. Периметр хвоїнки визначали за формулою Тирена (Blaschinskaia, 2014): $\Pi=\pi / 2 \cdot(1,137 b+a)$, де $\Pi-$ периметр хвоїнки, мм; $a-$ товщина хвоїнки, мм; $b$ - ширина хвоїнки, мм. Результати дослідження обробляли за допомогою Microsoft Office Excel 2007. Розраховували середню арифметичну похибку. Порівнювали морфо-анатомічні показники контрольних і дослідних варіантів за Student's t-test $(\mathrm{p}<0,05)$.

\section{Результати та їх обговорення}

Життєвий стан фітоценозу взагалі та конкретного дерева зокрема можна оцінити за характером розвитку асиміляційного апарату та його морфо-анатомічними показниками (Bessonova \& Ponomaryova, 2017; Suhareva, 2004). Нами виявлено, що довжина та маса хвоїнки $\epsilon$ чутливими до дії комплексу забруднювальних речовин $\mathrm{SO}_{2}, \mathrm{NO}_{x}$, тверді домішки, $\mathrm{CO}$ ростовими параметрами, оскільки у дослідних екземплярів P.pungens вони становлять лише 85,7 та 78,9 \% відповідно від значень цих показників у рослин умовно чистої зони (табл. 1).
Аналогічні результати для цього виду отримані за дії інших стрес-факторів середовища. Так, показано (Bessonova \& Ponomaryova, 2017) зменшення довжини, площі та маси хвоїнки у рослин P. pungens, які зростають вздовж автошляху та на віддаленні 10 м від нього, що автори пояснюють високою інтенсивністю руху автотранспорту й іншими екологічними чинниками, водночас на 120-метровій відстані значення цих характеристик практично не відрізнялись від контрольних.

Сухарєва T. А. (Suhareva, 2004) виявила зміни коефіцієнта інтенсивності росту хвої Picea obovata Ledeb. в умовах промислового забруднення i пропонує використовувати його як інформативну ознаку для оцінювання життєвого стану хвойних порід у техногенних зонах. Натомість наші дослідження показали (табл. 1), що за дії емісій Придніпровської ТЕС цей показник у P.pungens практично не змінюється (відмінності між контрольним і дослідним значеннями недостовірні при $\mathrm{p}<0,05)$, тому не може бути надійним тест-параметром для фітоіндикації стану популяцій ялини колючої в техногенних зонах.

Аналіз мікроморфологічних ознак хвої $P$. pungens (табл. 1) виявив стійкість до антропогенного тиску таких іiі характеристик, як ширина та товщина хвоїнки (відмінності між контрольними та дослідними значеннями недостовірні).

Таблиця 1

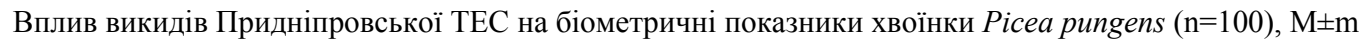

\begin{tabular}{|c|c|c|c|}
\hline Вид & Контроль & Придніпровська ТЕС & $t$ \\
\hline \multicolumn{4}{|c|}{ Морфометричні показники } \\
\hline Довжина хвоїнки, мм & $28,00 \pm 0,92$ & $24,00 \pm 0,54 * * * *$ & 3,75 \\
\hline Маса хвоїнки, мг & $17,28 \pm 1,38$ & $13,63 \pm 0,23 *$ & 2,61 \\
\hline Коефіцієнт інтенсивності росту хвої, мг / мм & $0,62 \pm 0,06$ & $0,57 \pm 0,05$ & 0,64 \\
\hline \multicolumn{4}{|c|}{ Мікроморфологічні показники } \\
\hline Ширина хвоїнки, мм & $1,29 \pm 0,21$ & $1,37 \pm 0,18$ & 0,78 \\
\hline Товщина (висота) хвоїнки, мм & $1,07 \pm 0,19$ & $1,17 \pm 0,16$ & 0,40 \\
\hline Периметр хвоїнки, мм & $3,98 \pm 0,11$ & $4,28 \pm 0,09 *$ & 2,11 \\
\hline Площа хвоїнки, мм² & $123,41 \pm 1,64$ & $114,42 \pm 1,33 * * *$ & 4,26 \\
\hline
\end{tabular}

* Дані достовірні при $\mathrm{p}<0,05 ; * *-$ при $\mathrm{p}<0,01$.

При цьому периметр хвоїнки дещо зростає (на 7,5\% порівняно $з$ контролем), однак ії площа зменшується (на $6,3 \%$ ), що пов'язано з істотним зниженням у техногенних умовах середовища довжини хвоїнки. Зменшення площі окремої хвоїнки може призвести до скорочення розмірів загальної асиміляційної поверхні пагонів, що, у свою чергу, може негативно позначитися на продуктивності дерев P.pungens та їх життєздатності в екстремальних умовах середовища.

На поперечному розрізі хвоїнка P.pungens має ромбоедричну форму і складається 3 покривних тканин, мезофілу і центрального провідного циліндра. Зовнішнім шаром голки $є$ комплекс покривних тканин: епідерма та гіподерма. Клітини епідерми мають товсті здерев'янілі стінки й вкриті кутикулою $з$ воску. У P. pungens продихи розміщені 3-4 паралельними поздовжніми рядами на гранях адаксіального та абаксіального боків хвоїнки. Продихи заглиблені в епідерму, що зменшує інтенсивність транспірації. Гіподерма розміщена вглиб від епідерми, складається 3 одного чи кількох шарів клітин 3 потовщеними стінками. Покривні тканини - основний бар'єр між зовнішнім середовищем і внутрішніми тканинами хвоїнки, а їх розміри - важлива діагностична ознака стану рослин у забруднених зонах.

Як видно 3 табл. 2, товщина обох складових покривів хвоїнки $P$. pungens - епідерми та гіподерми - за дії викидів Придніпровської ТЕС практично не змінюється (відмінності між контрольними та дослідними значеннями недостовірні при $\mathrm{p}<0,05)$. Аналіз літературних джерел свідчить про те, що під впливом антропогенних факторів довкілля розміри комплексу покривних тканин або окремих його елементів (епідерми, гіподерми чи кутикули) у чутливих видів хвойних зазвичай зменшуються, а у стійких - зростають. Так, в умовах міського середовища виявлено зменшення товщини кутикули й епідерми хвої рослин Abies sibirica Ledeb. (Sobchak et al., 2004). Коефіцієнт мінливості для товщини покривних тканин хвої $P$. sylvestris за умов техногенного стресу становив 10,9\% (Fedorkov, 2011). На думку автора, природний добір сприяє виживанню дерев 3 більш розвиненими покривними тканинами. Виявлено (Legoshchina et al., 2013) зниження в хвої P. obovata розмірів кутикули та гіподерми й одночасне зростання товщини епідерми еквівалентно рівню антропогенного навантаження.

Під покривними тканинами розміщена асиміляційна тканина - складчастий мезофіл. Його оболонки утворюють складки всередину клітини, збільшуючи площу поверхні клітинних стінок і поверхневого шару цитоплазми, в якому містяться хлоропласти. Така будова дозволяє в малому об'ємі клітини збільшити інтенсивність фотосинтезу. Мезофіл містить 2 (рідше 1) смоляні ходи, вистелені зсередини живими епітеліальними секреторними клітинами 3 тонкими оболонками, які продукують смоли. Ззовні смоляні ходи оточені шаром лігніфікованих склеренхімних клітин. За розміщенням смоляні ходи P.pungens периферійні (крайові), оскільки вони прилягають до гіподерми багатьма клітинами. 
Таблиця 2

Вплив викидів Придніпровської ТЕС на товщину покривних тканин і мезофілу хвоїнки Picea pungens, мкм

\begin{tabular}{cccc}
\hline Показник & Контроль & Придніпровська ТЕС & $t$ \\
\hline Товщина епідерми & $20,97 \pm 1,78$ & $19,34 \pm 2,14$ & 0,59 \\
Товщина гіподерми & $29,84 \pm 1,72$ & $28,83 \pm 3,19$ & 0,002 \\
Товщина мезофілу адаксіального боку, мкм & $391,16 \pm 9,24$ & $419,38 \pm 10,56^{*}$ & 2,01 \\
Товщина мезофілу абаксіального боку, мкм & $457,29 \pm 12,73$ & $454,87 \pm 15,56$ & 0,12 \\
Кількість смоляних ходів, шт. & $1,50 \pm 0,07$ & $1,70 \pm 0,15$ & 0,88 \\
Діаметр смоляного ходу, мкм & $83,60 \pm 6,89$ & $76,23 \pm 2,12$ & 1,02 \\
\hline
\end{tabular}

*Дані достовірні при $\mathrm{p}<0,05$.

Аналіз отриманих даних свідчить про наявність асиметрії в розташуванні мезофілу і ЦПЦ в хвоїнках дослідженого виду як в умовах чистої зони, так і на забрудненій території (табл. 2). Мезофіл P. pungens в обох моніторингових точках товщий з абаксіального (нижнього) боку хвоїнки, а його розміри за умов техногенезу практично не змінюються (відмінності між контрольними та дослідними значеннями недостовірні при $\mathrm{p}<0,05)$. Товщина асиміляційної паренхіми 3 адаксіального боку листка в умовах техногенезу збільшується і становить $113,3 \%$ від значення цього показника у рослин умовно чистої зони.

У P.pungens, що зростає на прилеглій до Придніпровської ТЕС території, кількість і діаметр смоляних ходів, а також тип розміщення їх у мезофілі хвоїнки практично не відрізняються від таких показників у рослин Ботанічного саду ДНУ, що свідчить про стабільність цих ознак та стійкість хвої дослідженого виду до викидів ТЕС.

У літературі наявні роботи щодо дії промислових викидів на будову мезофілу різних видів хвойних (Atkina \& Vishnyakova, 2007; Sobchak et al., 2004 та ін.). Показано (Report .., 2005), що за екстремальних техногенних умов зростання дерев $P$. sylvestris протягом періоду вегетації відсоткове співвідношення площі хвоїнки до площі поперечного зрізу смоляних ходів не змінюється. За даними (Legoshchina et al., 2013), відбувається зниження площі мезофілу в хвої P. obovata по мірі наближення до промислової зони м. Кемерово. У хвоїнках рослин Picea abies (L.) H. Karst, що зростали вздовж автошляху, виявлено (Atkina, Vishnyakova, 2007) асиметрію в розташуванні провідного пучка, що може бути наслідком нестачі пластичних речовин (рослина багато ресурсів витрачає на подолання стресу).

Центральну частину хвоїнки складає центральний провідний циліндр (ЦПЦ), оточений одним рядом клітин ендодерми із поясками Каспарі на радіальних стінках. Отже, ендодерма слугує «внутрішньою покривною тканиною» ЦПЦ і виконує бар'єрну функцію. ЦПЦ P.pungens містить трансфузійну тканину, в якій розташований один провідний пучок. Він складається із ситоподібних елементів флоеми, що забезпечують відтікання фотоасимілятів із хвоїнки до інших органів рослини (низхідна течія), та ксилемних трахеїд, якими із стебла до хвоїнки надходять вода i мінеральні солі (висхідна течія).

Нами виявлено, що серед гістологічних елементів хвої P. pungens найбільшого впливу викидів Придніпровської ТЕС зазнають складові ЦПЦ (табл. 3). Слід відзначити потовщення на 15,9 \% порівняно 3 контрольним значенням шару ендодерми, що ми розглядаємо як адаптивну реакцію рослин на техногенний стрес. У ялин забрудненої зони збільшується і діаметр ЦПЦ, що корелює з потовщенням ксилеми. Імовірно, це необхідно для кращого водозабезпечення рослин, оскільки поблизу великих ТЕС температура повітря на $2-3{ }^{\circ} \mathrm{C}$ вища (Rodionov, 2010) і для підтримання на належному рівні процесу фотосинтезу рослини мають збільшувати інтенсивність транспірації. У літературі зустрічається низка робіт, які свідчать що в умовах урбосередовища знижується площа ЦПЦ у голках різних хвойних: A. sibirica (Sobchak et al., 2004), P. obovata (Legoshchina et al., 2013) та P. sylvestris (Soboleva et al., 2009).

Наведені в табл. 2-3 дані виражені в мікрометрах. На рис. 1 представлені значення гістологічних показників у відносних величинах, тобто частка кожної тканини у відсотках по відношенню до загальної ширини хвоїнки. Аналіз цих даних свідчить, що суттєві відмінності у співвідношенні анатомічних характеристик листка P. pungens за дії викидів Придніпровської ТЕС відсутні. $\mathrm{У}$ рослин забрудненої зони незначно змінюються лише частки мезофілу та гіподерми, але ці зміни знаходяться в межах звичайної мінливості.

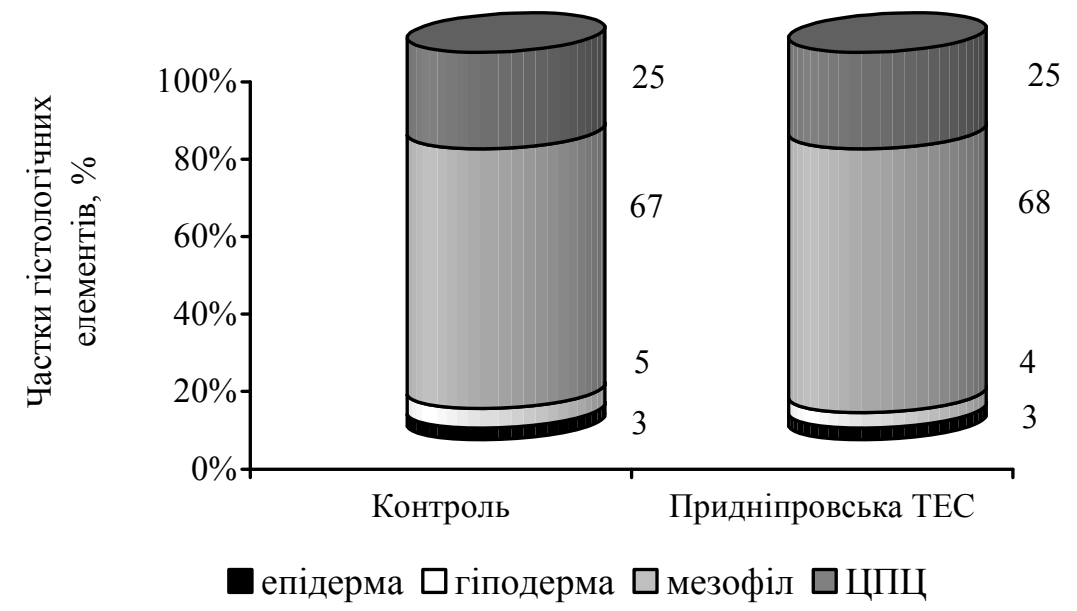

Рис. 1. Вплив викидів Придніпровської ТЕС на розміри гістологічних елементів хвоїнки Picea pungens, \% 
Таблиця 3

Вплив викидів Придніпровської ТЕС на розміри гістологічних елементів центрального провідного циліндра хвоїнки Picea pungens, мкм

\begin{tabular}{lccc}
\hline \multicolumn{1}{c}{ Показник } & Контроль & Придніпровська ТЕС & $t$ \\
\hline Товщина ендодерми & $14,62 \pm 0,75$ & $16,94 \pm 0,81^{*}$ & 2,10 \\
Діаметр центрального провідного циліндра & $322,60 \pm 4,81$ & $354,86 \pm 3,40^{*}$ & 6,13 \\
Товщина флоеми & $58,88 \pm 3,81$ & $55,45 \pm 1,83$ & 0,81 \\
Товщина ксилеми & $75,81 \pm 2,15$ & $85,49 \pm 3,23 *$ & 2,50 \\
\hline
\end{tabular}

* Дані достовірні при $\mathrm{p}<0,05$.

\section{Висновки}

1. Забруднення навколишнього середовища викидами Придніпровської ТЕС призводить до зміни інтенсивності росту асиміляційних органів P.pungens, внаслідок чого знижуються маса, довжина та площа хвоїнок. До адаптивних механізмів компенсаторного типу належать збільшення в хвоїнках $P$. pungens під впливом забрудників товщини ендодерми, мезофілу адаксіального боку, ксилеми та діаметра центрального провідного циліндра.

2. Гістологічні характеристики є стабільними ознаками для виду P. pungens, а лінійні розміри хвої - пластичними, які змінюються за дії фітотоксикантів.

3. Виявлені чутливі до діоксидів нітрогену та сульфуру, оксиду карбону (II) i твердих домішок морфометричні та мікроморфологічні показники (маса, довжина та площа хвоїнки) P. pungens, які ми пропонуємо використовувати в моніторингових дослідженнях.

4. P. pungens виявила середню стійкість морфологогістологічних показників до викидів Придніпровської ТЕС, тому цю деревну породу можна використовувати в озелененні техногенних територій, забруднених комплексом речовин $\left(\mathrm{SO}_{2}, \mathrm{NO}_{2}\right.$, тверді домішки, $\left.\mathrm{CO}\right)$.

\section{References}

Albrechtova, J. (2003). Plant Anatomy in Environmental Studies, Prague.

Antonova, G. F., Stasova, V. V. (2002). Seasonal distribution of processes responsible for radial diameter and wall thickness of larch (Larix sibirica Ldb.) tracheids. Improvement of larch (Larix sp.) for better growth, stem form and wood quality. Proceedings of an International Symposium. Gap (Hautes-Alpes). France, INRA Cemagref, 369-377.

Atkina, L. I., Vishnyakova, S. V. (2007). Vliyanie vybrosov avtotransporta na anatomicheskie osobennosti hvoi eli obyknovennoj v usloviyah Ekaterinburga [Influence Surge Motor Transport on Anatomical Particularities of Pineneedles Ated to Be Common in Condition Ekaterinburg]. Forestry Bulletin, 8, 4-7 (in Russian).

Bessonova, V. P. (2006). Vliyanie tyazhelyh metallov na rasteniya [The Influence of Heavy Metals on Photosynthesis of Plants]. Dnipropetrovsk State Agrarian University, Dnipropetrovsk (in Russian).

Bessonova, V. P., Ponomaryova, O. A. (2017). Morfometrychni pokaznyky ta vmist plastydnykh pihmentiv khvoi Picea pungens zalezhno vid vidstani do avtoshliakhu [Morphometric characteristics and the content of plastid pigments of the needles of Picea pungens depending on the distance from the highways]. Biosystems Diversity, 25(2), 96-101 (in Ukrainian).

Bessonova, V., Iusypiva, T. (2018). Morfoanatomichni pokaznyky khvoi Pinus pallasiana D. Don. u riznykh lisoroslynnykh umovakh protyeroziinoho nasadzhennia [Morpho-anatomical parameters of the needles of Pinus pallasiana D. Don. in the antierosion afforestation]. Ukrainian Journal of Ecology, 8(1), 851-858 (in Ukrainian).
Bessonova, V. P., Usypiva, T. I. (2001). Semennoie vozobnovlenie drevesnykh rasteniy $\mathrm{i}$ promyshlennyie pollutanty $\left(\mathrm{SO}_{2} \mathrm{i} \mathrm{NO}_{2}\right)$ [Seed renewing of arboreal plants and industrial pollutants $\left(\mathrm{SO}_{2}\right.$ and $\left.\mathrm{NO}_{2}\right)$ ]. Zaporizhzhya University Press, Zaporizhzhya (in Russian).

Blaschinskaia, O. N. (2014). Baryernyye svoystva drevesnogo rastitelnogo pokrova (sosna obyknovennaya i bereza povislaya) urbanizovannoy territorii (na primere $\mathrm{g}$. Angarska Irkutskoy oblasti) [Barrier properties of woody vegetation cover (common pine and birch dangling) of the urbanized territory (on the example of the city of Angarsk in the Irkutsk region)]. Doc. Diss. Irkutsk (in Russian).

Dmuchowski, W., Kurczynska, E. U., Wloch, W. (1998). Chemical Composition of Needles and Cambial Activity of Stems of Scots Pine Trees Affected by Air Pollutants in Polish Forests. USDA Forest Service Gen.Tech.Rep. PSWGTR-166. Available at http://www.fs.fed.us/psw/publications/documents/psw_gtr1 66/psw_gtr166_003_dmuchowski.pdf

Grytsay, Z., Miasoid, G. (2016). Assessment of Floral Organs State of Tilia Genus Representatives under Environment Pollution Conditions caused by Emissions of Prydniprovska Thermal Power Plant, Dnipropetrovsk city. International Letters of Natural Sciences, 55, 52-56 (in Ukrainian).

Griztay, Z. V., Shupranova, L. V. (2015). Vplyv vykydiv Prydniprovskoi TES m. Dnipropetrovsk na anatomichni pokaznyky stebla dvorichnoho pahona predstavnykiv rodu Tilia [Impact of Emissions of Pridneprovsk TPP in Dnipropetrovsk on the Anatomical Indices of Stem of Two-Year Whip of the Tilia Genus Representatives]. Vìsn. Dnìpropetr. Unìv. Ser. Bìol. Ekol, 23(2), 230-235 (in Ukrainian).

Ekolohichnyi pasport mista Dnipro (2016 r.) [Ecological passport of the Dnipro Sity (2016 p.)]. Available at https://nniprorada.gov.ua/upload/editor/Екологічний\%20п аспорт.PDF. (in Ukrainian).

Ekolohichnyi pasport Dnipropetrovskoi oblasti (2015 r.) [Ecological passport of the Dnipropetrovsk Region] // http://old.menr.gov.ua/docs/protection1/dnipropetrovska/D nipropetrovska_ekopasport 2015.pdf

Iusypiva, T., Miasoid, G. (2017). The Impact of Industrial Pollution with Toxic Gases on the Stem Anatomical Characteristics of Woody Plant Undergrowth in the City of Dnipro, Ukraine. International Letters of Natural Sciences, $65,1-9$.

Legoshchina, O. M., Neverova, O. A., Bykov, A. A. (2013). Izmenchivost' anatomicheskoj struktury hvoi $\mathrm{v}$ usloviyah vliyaniya vybrosov promzony g. Kemerovo [The variability of the Anatomical Structure of Pine Needlesof Picea obovate Ledeb. under the Effect of Emissions from the Industrial Zone of Kemerovo]. Contemporary Problems of Ecology, 5, 733-739 (in Russian).

M. Dnipropetrovs`k general'ny`j plan rozvy`tku mista (2015). [The City of Dnipropetrovsk, Amending the general plan of the city development]. Kyiv (in Ukrainian).

Otchet o nauchnoj i nauchno-organizacionnoj deyatel'nosti laboratorii lesovedeniya za 2005 god po teme: «Adaptivnye osobennosti i harakteristika ustojchivosti lesoobrazuyushchih vidov Yuzhnogo Urala k ehkstremal'nym prirodnym i tekhnogennym usloviyam» 
[Report on the scientific and organizational activities of the laboratory of forest studies for 2005 on the topic: «Adaptive features and characteristics of the resistance of forest-forming species of the Southern Urals to extreme natural and man-made conditions»] Available at https:/a/upload/editor/Екологічний\%20паспорт.PDF// forestry.chat.ru> otchet-05.htm

Pasichnyy, H. V., Serdyuk, V. M. (2002). Dynamika vazhkykh metaliv $\mathrm{v}$ gruntovomu pokryvi u zv'yazku z tekhnohennym zabrudnennyam otochuyuchoho seredovyshcha (na prykladi m. Dnipropetrovs'ka) [Dynamics of Heavy Metals in the Soils is Dealt with the Technogenic Pollution of Environment (for Example of Dnepropetrovsk City)]. Ecology \& Natural Resource Management, 4, 111-117 (in Ukrainian).

Permjakov, A. I. (1988). Mikrotehnika [Microtechnica]. Moscow University Press, Moscow. (in Russian).

Rodionov, V. G. (2010). Energetika: problemy nastoyashchego i vozmozhnosti budushchego [Energy: problems of the present and the possibilities of the future]. ENAS, Moscow. (in Russian).

Fedorkov, A. L. (2011). Izmenchivost adaptivnykh priznakov khvoynykh $\mathrm{v}$ usloviyakh stressa na severe Evropy. [Variability of adaptive signs of conifers under stress in northern Europe]. Doc. Diss. Moscow (in Russian).

Sobchak, R. O., Degtyareva, O. N., Astafurova, T. P. (2004). Kompleksnaya ocenka sostoyaniya pihty sibirskoj Abies sibirica Ledeb. V usloviyah gorodskoj sredy. [Comprehensive assessment of the status of Siberian fir
Abies sibirica Ledeb. in urban environment]. Conifers of the boreal area, $\mathrm{XXV}(2), 100-109$ (in Russian).

Soboleva, O. M., Kondratenko, E. P., Pinchuk, L. G. (2009). Kompleksnaya ocenka sostoyaniya assimilyacionnogo apparata sosny obyknovennoj v g. Novokuzneck [Comprehensive assessment of the state of the assimilation apparatus of Scots pine in Novokuznetsk]. Vestnik AGAU, 33-36 (in Russian).

Sungurova, N. R., Khudyakov, V. V. (2015) Assimilyatsionnyy apparat $\mathrm{v}$ kulturakh sosny [Assimilatory apparatus of pine cultures]. Proceedings of Petrozavodsk State University, 81 (153)]. 68-74 (in Russian).

Suhareva, T.A. (2004). Himicheskij sostav i morfometricheskie harakteristiki hvoi eli sibirskoj v usloviyah vozdushnogo promyshlennogo zagryazneniya [Chemical composition and morphometric characteristics of Siberian spruce needles under conditions of industrial air pollution]. Doc. Diss. Apatity (in Russian).

Stasove, V. V., Perevoznikova, V. D., Zubareva, O. N., Tatarintsev, A. I. (2009). Vliyanie kompleksa tekhnogennyh i rekreacionnyh nagruzok na razvitie tkanej stvola sosny obyknovennoj v Krasnoyarskoj lesostepi [The Influence of the Complex of Technogenic and Recreational Burden on the Development of the Stem Tissues of Scotch Pine in Krasnoyarsk forest-steppe]. News of RAS. Biological Series, 5, 618-626 (in Russian).

Zlobin, Yu. A., Sklyar, V. G., Bondareva, L. M., Kyrylchuk, K. S. (2009). Kontseptsiia morfometrii v suchasnii botanitsi [The morphometric concept in modern botany]. Chornomors'k Botanical Journal, 5 (1), 5-22 (in Ukrainian). 